$$
\text { carf-78.4.30--6 }
$$

\title{
FRICTION, WEAR, AND CORROSION OF LAVES-HARDENED NICKEL ALLOY HARDSURFACING IN SODIUM
}

R. N. Johnson and D. G. Farwick

\section{ABSTRACT}

This paper represents the results of friction, wear, and corrosion tests on Tribaloy 700 specimens. The Tribaloy alloys are a fomily of materials typiuully consisting of a hard, intermetallic Laves phase dispersed in a cobalt or nickel eutectic or soiicl solution matrix. only one alloy of the Tribaloy series, Tribaloy 700, is a cobalt-free nickel-base alloy. Tribaloy 700 is therefore of interest for nuclear reactor applications, where cobalt must be restricted.

Tribaloy 700 mbbing against itself in sodium exhibited among the lowest friction coefficients measured for metallic materials at high temperature. Detonationgun coatings had lower friction and lower corrosion rates than nlasma coatings, in general. The wear rate of Tribaloy 700 was negligible. Surface domage resistance was good, especially when in contract with itself or other haxd materials. The material also exhibited low corrosion rates in sodium. 


\section{DISCLAIMER}

This report was prepared as an account of work sponsored by an agency of the United States Government. Neither the United States Government nor any agency Thereof, nor any of their employees, makes any warranty, express or implied, or assumes any legal liability or responsibility for the accuracy, completeness, or usefulness of any information, apparatus, product, or process disclosed, or represents that its use would not infringe privately owned rights. Reference herein to any specific commercial product, process, or service by trade name, trademark, manufacturer, or otherwise does not necessarily constitute or imply its endorsement, recommendation, or favoring by the United States Government or any agency thereof. The views and opinions of authors expressed herein do not necessarily state or reflect those of the United States Government or any agency thereof. 


\section{DISCLAIMER}

Portions of this document may be illegible in electronic image products. Images are produced from the best available original document. 


\section{FRICTION, WEAR, AND CORROSION OF LAVES-HARDENED NICKEL ALLOY HARDSURFACING IN SODIUM}

R. N. Johnson and D. G. Farwick

\section{INTRODUCTION}

Nuclear reactor service places special demands on wear-resistant, lowfriction hardsurfacing materials. Materials for use in breeder reactors must exhibit.long, low-maintenance lifetimes in environments of neutron irradiation and high-temperature liquid metal coolant.

Specifically, the desirable properties of hardsurfacing materials for sodium-cooled reactors are: low friction plus good wear and galling resis- c tance, both when mated against themseives and against other materials; retention of adequate mechanical properties, such as hardness and yield strength, at temperatures up to $1200 \mathrm{~F}\left(650^{\circ} \mathrm{C}\right)$; corrosion resistance and freedom from formation of compounds or deposits on the surface, which would degrade the friction or wear performance; and absence of constituents such as cobalt or boron which, in reutron flux environments, can transmute to undesirable isotopes or capture excessive quantities of neutrons.

Since most metallic hardfacings for high-temperature applications contain cobalt or boron, the number of metallic hardfacings available for sodium service in and near reactor cores is very limited. When a new class of 
nickel-base alloys with attractive high-temperature properties becomes available, therefore, investigation of the material for its possible in-sodium applications is amply justified.

In 1973, Industrial Research magazine selected the Tribaloy(a) alloys as one of the 100 most significant new developments of the year. These alloys, which were developed by E. I. du Pont de Nemours and Company and later sold to Cabot Corporation, were found to be especially suited to unlubricated wear applications. They exhibit good corrosion resistance and good wear and galling resistance, both against themselves and against other materials. The alloys are also fabricable in a variety of product forms.

The Tribaloy alloys are a family of materials typically consisting of a hard, intermetallic Laves-phase dispersed in a cobalt or nickel eutectic or : solid solution matrix. Of the available Tribaioy series, only one, Tribaloy 700, is a cobalt-free nickel-base alloy, and of interest for nuclear applications where cobalt must be restricted.

II. SUMMARY RIND CONCLUSIONS

Tribaloy 700 rubbing against itself in sodium exhibits among the lowest friction coefficients measured for metallic materials at high temperature. Coatings of Tribaloy 700 on Type 316 stainless steel. showed good corrosion

(a) Trademark, Cabot Corp. 
resistance in sodium at $625^{\circ} \mathrm{C}$. Detonation-gun coatings had lower friction and lower corrosion rates than plasma coatings, in general. In thermal cycling tests in sodium, detonation-gun coatings were unaffected by 120 cycles, while all plasma coatings except a special duplex coating cracked or spalled within 30 cycles. The duplex coating, consisting of Tribaloy 700 deposited on a sub-layer of 50 vol.\% Tribaloy 700 and 50 vol.\% Type 316 on a Type 316 stainless steel suhstrate, proved effective in reducing interface stresses due to thermal expansion differences, and was the only plasma coating to survive the complete series of corrosion and thermal cycling tests.

The wear rate of Tribaloy 700 under all test conditions was negligible. Surface damage resistance was good, especially when in contact with itself or other hard materials. The type of wear tended to be of the mild abrasive : or polishing nature, but some instances of adhesive wear were found when Tribaloy 700 was rubbed against such materials as Inconel 718.

Tribaloy 700 exhibited low friction, excellent wear resistance, and low corrosion rates in sodium. It is well suited for use in high-temperature liquid metal environments. Its freedom from cobalt makes it particularly attractive for nuclear applications. The increasing world prices of cobalt supplies will also add to the economic attractiveness of this and other cobalt-free hardfacing materials. 
III. STRUCTURES AND PROPERTIES

\section{A. $\quad$ Structure}

The typical Tribaloy alloy consists of a hard, intermetallic Laves phase, which provides wear resistance, dispersed in a softer matrix of eutectic or solid solution. In Tribaloy 700 the Laves phase is a close-packed hexagonal compound of the $\mathrm{A}_{2} B$ Type (or $\mathrm{MgZn}_{2}$ structure), where the $A$ atoms may be either nirkel or siliron, and $B$ atoms may be either molybdenum or chromium. (1) The Laves phase may be represented as $(\mathrm{NiSi})_{2}(\mathrm{Mo}, \mathrm{Cr})$. The matrix phase of Tribaloy 700 is face-centered cubic. The composition of Tribaloy 700 is $50 \mathrm{Ni}-32 \mathrm{Mo}-15$ $\mathrm{Cr}-3 \mathrm{Si}$ (Wt\%), and the Laves phase formed is usually about $60 \%$ of the volume. Figure la shows the microstructure of weld-deposited Tribaloy 700. (2)

\section{B. Properties}

Since Tribaloy 700 is a recent addition to the Tribaloy series of alloys, little information on physical or mechanical properties is available. To date the only reported mechanical preperty has been the hardness of weld-deposited material. Westinghouse Advanced Reactors Division (WARD) ${ }^{(3)}$ reported the hardnesses of weld-deposited Tribaloy 700 on 316 stainless steel samples used for self-welding tests before and after 6 months exposure to $540 \mathrm{C}(1000 \mathrm{~F})$ sodium as Rockwell A 75 and 81 , respectively. 


\section{COATINGS}

The first reactor application for which Tribaloy 700 was considered was as a low-friction material for fuel assembly and other core component wear pads in the Fast Flux Test Facility (FFTF). Qualification tests on Tribaloy 700 for this application are still in progress. Plasma-spraying and detonation-gun processes were chosen for evaluation since both maintained the $20 \%$ cold-worked substrates at low enough temperatures to prevent distortion or metallurgical modification.

\section{A. Coating Processes}

The plasma-arc process, the detonation-gun process, and the required substrate preparation techniques have been described in a previous paper. (4)

Test specimens plasma-coated with Tribaloy 700 were obtained from several vendors to determine if minor differences in processing equipment and techniques significantly affected the coating quality or performance. Plasma spray equipment used by the vendors included Metco, Plasmadyne, and Union Carbide prasma arc guns, and a high-velocity "Mach II" plasma gun from Plasmadyne. Detonation-gun coatings were supplied by Union Carbide.

The coatings were examined in the vendor's facilities by bond strength tests (epoxy lift-off test in accordance with ASTM-C-633-69) 
and by metallographic examination. Plasma coatings always failed within the coating or at the coating/substrate interface at typical tensile loads of 5000 to 9000 psi ( 35 to $62 \mathrm{MPa}$ ). Tests on the detonation-gun coatings always resulted in failure of the epoxy testing medium at loads in excess of 10,000 psi (69 MPa). Typical photomicrographs of a detonation-gun coating and of a plasma coating of Tribaloy 700 on Type 316 stainless steel are shown in Figures $1 b$ and $1 c$.

\section{Coating Parameters}

- Thickness - For both plasma and detonation-gun coatings, the coating thickness applied to all test specimens was nominally $100 \mu \mathrm{m}$ (0.004 in.) thick.

- Finishing - The finishing technique found to provide lowest friction in sodium consisted of brushing the surface with a silicon-carbide-impregnated nylon flap brush (such as the 3M Company's $5 S$ Fine Finishing Flap Brush) to a surface finish of 1.5 to $2.5 \mu \mathrm{m}$ (60 to $100 \mu \mathrm{in.}$ ) arithmetic average. This process tends to relief-grind the soft phase and to leave the harder Laves phase exposed with the sharper peaks rounded off and polished. The result is a surface with a smooth nodular texture. 


\section{EVALUATION TESTING}

Testing of Tribaloy 700 has been conducted for the U.S. Department of Energy (DOE) under the National Friction, Wear, and Self-Welding Program. This program consists of a cooperative test and development arrangement among several DOE contractor laboratories. Materials development and vendor qualification is performed by the Hanford Engineering Development Laboratory (HEDL). Friction and wear testing in sodium, sodium vapor, inert gas, and air are conducted at the Liquid Metal Engineering Center (LMEC) and at Westinghouse Advanced Reactors Division (WARD). Self-welding tests, corrosion tests and thermal cycling tests in sodium are also conducted at WARD. Friction screening tests were performed by Atomics International (AI) under a portion of the program now completed. Irradiation testing of hardsurfacing materials and the overall National Program coordination and direction are performed by HEDL.

\section{A. Friction Tests}

For most sodium-cooled reactor applications, friction coefficients of mating interfaces are of greater concern than wear or corrosion rates (although minimum requirements are also established for these properties). This is because most components experience relatively little total rubbing, but when required to move must do so with great reliability and without causing excessive stresses to occur in critical structural members. 
The majority of the friction tests were conducted in sodium under conditions prototypic of design service requirements for core component interfaces. A small number of tests were conducted in argon and sodium vapor, and some tests included brief rubbing periods in air. Most tests were of Tribaloy 700 versus Tribaloy 700 , but results of some tests of Tribaloy 700 versus other materials are also presented.

\section{Tribaloy 700 Versus Itself in Sodium}

The initial tests of Tribaloy ico versus itself were conducted as part of the friction screening test series. These tests included Tribaloy 700 deposited by plasma spray, by Gas Tungsten Arc (GTA) welding, and by detonation gun, all on austenitic stainless steel substrates. The results showed that Tribaloy 700 exhibited among the lowest friction coefficients measured for metallic materials in the screening program ${ }^{(5)}$, ranging from 0.15 to 0.4 at the lower temperatures $\left(<400^{\circ} \mathrm{C}\right)$ to 0.3 to 0.6 at the higher temperatures (up to $625^{\circ} \mathrm{C}$ ). The detonation-gun coating usually displayed the lowest friction coefficients of the various product forms of Tribaloy 700.

The results of the screening test warranted continued testing of Tribaloy 700 under more extensive conditions prototypic of reactor applications, particularly core component wear pads. Tests were conducted primarily on the detonation-gun coatings, since not only were the friction coefficients lower, but these coatings 
appeared to be more stable and resistant to damage in sodium than the plasma-sprayed coatings, as will be discussed later.

Tests were conducted at WARD and at $\operatorname{LMEC}(5,7,8)$ on detonation-gun coatings of Tribaloy 700 at temperatures from $230^{\circ} \mathrm{C}$ $\left(450^{\circ} \mathrm{F}\right)$ to $625^{\circ} \mathrm{C}\left(1160^{\circ} \mathrm{F}\right)$. Tests were run in sudium containing 0.5 to $1.0 \mathrm{ppm}$ oxygen, at loads of 2 and $7 \mathrm{MPa}$ (300 and $1000 \mathrm{psi}$ ). The test mode consisted of oscillatory rubbing of flat-ended cylindrical pins against a flat plate with a stroke length of 0.25 to 1.2 times the pin diameter. Changes in stroke length, however, created no observable changes in the friction behavior. The average velocity of rubbing was $2.5 \mathrm{~cm} / \mathrm{min}(1.0 \mathrm{jpm})$.

Figure 2 presents a test profile simulating service conditions at two loads, and shows consecutive periods of continuous rubbing at various temperatures. The graph is presented as a band encompassing both average arid maximum friction coefficient values found in all tests.

The dwe 11 period shown during the $625^{\circ} \mathrm{C}$ rubbing sequence represents an interval of contact under both normal and tangential load, but no motion, for a period of nearly three days. During this dwell time two processes take place: (1) Diffusion bonding (self-welding) starts to occur, resulting in a high breakaway friction coefficients (nearly 1.4 in these tests; (2) At the same time 
sodium-metal-oxygen complex films may form that are lubricative, and lower subsequent dynamic friction coefficients until worn away by rubbing. The kinetics of formation and the stability of these films are complex functions of temperature, oxygen concentration in the sodium, and chemical activity of the reacting elements (usually chromium) in the surface.

2. Friction of Tribaloy 700 Versus Other Materials in Sodium

Auriong the screening tests ${ }^{(5)}$ conducted at AI were three tests of weld-deposited Tribaloy 700 versus other materials, which included Incone $718^{(a)}$, aluminized Inconel 718 , and welddeposited Tribaloy $400^{(b)}$ (a cobalt-hased hardfacing alloy). The test results, (9) Figure $3 a$, show that these dissimilar materials couples display the same general friction behavior as the Tribaloy 700-versus-self couples, with the exception of the Tribaloy $700 /$ aluminized Inconel 718 couple (Figure 4). This combination exhibited a more uniform friction coefficient relatively independent of temperature.

\section{Friction of Tribaloy 700 in Gases}

While most tests on Tribaloy 700 were conducted in sodium, some friction data were obtained in pure argon and in air (both at

\footnotetext{
(a) Trademark, International Nickel Co.

(b) Trademark, Cabot Corp.
} 
room temperature) during preparation for the tests in other environments at higher temperatures. In addition, a few of the friction screening test series ${ }^{(9)}$ at AI were performed in argon containing sodium vapor.

Figure $3 b$ shows friction-versus-temperaturs curves for several combinations of Tribaloy 700 against itself and against other materials in the argon/sodium vapor atmosphere.

\section{B. Wear and Surface Damage}

Wear and surface damage were measured on the friction test specimens after completion of all rubbing in the tests described previously. Material losses were found to be too small under the test conditions employed to obtain meaningful quantitative wear coefficients. However, qualitative assessments of wear and surface damage were made visually and microscopically and are described below.

\section{Wear of Tribaloy 700 Against Itself}

Wear of Tribaloy 700 against itself was negligible under all test conditions used, including sodium, sodium vapor, and inert gas environments. Surfaces typically showed polishing of asperities or mild abrasive wear. Product forms tested included detonation-gun coatings, plasma coatings, and weld-deposited hardfacings, all on Type 316 stainiess steel substrates. 
Figure 4 shows a typical detonation-gun coating after the test described in Figure 2, which included $57 \mathrm{~m}$ (2240 in.) of rubbing at $6.9 \mathrm{MPa}(1000 \mathrm{psi})$ at temperatures to $627^{\circ} \mathrm{C}\left(1160^{\circ} \mathrm{F}\right)$.

Plasma-sprayed coatings of Tribaloy 700 rubbing against themselves in sodium showed little surface damage and mild wear. Coatings from some vendors, however, prematurely failed in wear tests due to spaliing. (Most plasma-sprayed coatings however, eventually spalled in corrosion or thermal cycling tests in sodium, as will be discussed later.) We1d-deposited Tribaloy 700, although not tested as exiensively as other forms, showed the same resistance to surface damage as the detonation-gun and plasma-sprayed coatings in the screening tests.

2. Wear of Tribaloy 700 Against Other Materials

The tests of Tribaloy 700 rubbing against other materials were all conducted under the friction screening test conditions. (5) Tests in sodium included weld-deposited Tribaloy 700 rubbing against Tribaloy 400, Inconel 718 , and aluminized Incone 1 718. Only polishing wear was observed in the Tribaloy $700 /$ Tribaloy 400 couple. While the Tribaloy $700 /$ aluminized Inconel 718 couple showed predominantly mild abrasive wear and polishing, a small amount of Tribaloy 700 transferred by adhesion to the surface of the harder aluminized Incone1 718. Two tests on 
Tribaloy 700 against Inconel 718 conducted under identical conditions showed only polishing and mild abrasive wear in one test, but adhesive wear damage, primarily to the Inconel 718 , in the other test.

Tests in inert gas and sodium vapor includad Tribaloy 700 (plasma coated) rubbing against Inconel 718 , aluminized Inconel 718, or Niresist alloy. In ail cases only polishing and mild abrasive wear were observed.

C. Corrosion and Thermal cycling

The Tribaloy 700 coatings were applied to Type 316 stainless steel substrates by either Union Carbide's detonation-gun process or by var- , ious types of plasma processes. Plasma processes included the "normal" plasma processes of Union Carbide, Plasma Technology Inc. and Quantum, Inc.; a high-velocity plasma process using Plasmadyne's Mach II equipment; and a special duplex coating applied by Quantum's plasma process. The duplex coating consisted of an intermediate iayer of a mixture of Tribaloy $700+50$ vol.\% Type 316 stainless steel between the Type 316 substrate and the top layer of Tribaloy 700.

Only two Tribaloy 700 coatings survived the complete series of corrosion and thermal cycling tests: the detonation-gun coatings and the duplex plasma coating. All other plasma coatings by all the other 
processes failed by cracking and spalling of the coating, continuing a pattern found in tests on plasma coatings of other materials (4, 10, 11, ). Cracking and spalling usually occurred within the first 30 thermal cycles. Figure 5 shows an example of a typical plasma coating failure. The success of the detonation-gun coating is attributed to the superior bond strerigth and coating density achievable by this. process. The survival of the duplex plasma coating is attributed to a reduction of the interface stresses caused by thermal expansion differences.

Average corrosion rates of detonation-gun applied and duplex plasma coatings of Tribaloy 700 were measured as $2.5 \mathrm{\mu m}(0.1 \mathrm{mil})$ per year and $4 \mu \mathrm{m}(0.16 \mathrm{mil})$ per year, respectively. Both the corrosion and wear rates are sufficiently low that coating thicknesses could be reduced to $50 \mu \mathrm{m}(0.002 \mathrm{in.})$ for most sodium-cooled reactor applications. The thinner coatings further reduce interface stresses and increase the resistance of the coating to cracking and spalling.

\section{ACKNOWLEDGMENTS}

This paper presents the results of the combined efforts of several companies and many individuals who participated in the U.S. Department of Energy's National Friction, Wear, and Self-Welding Program, under the technical direction of the Hanford Engineering Development Laboratory. The authors particularly acknowledge the expert work and assistance of the following individuals: P. H. Horton, R. M. Oliva, and W. J. Kurzeka of Atomics 
International. Canoga Park, CA, for performing friction screening tests; N. J. Hoffman and J. J. Droher, Liquid Metal Engineering Center, Canoga Park, Ca, for wear and friction testing; T. A. Galioto and W. L. Wilson for wear and friction testing, G. A. Whitlow and R. L. Miller for corrosion and thermal cycle testing, J. Y. Chang for self-welding studies, and M.G. Cowgill and S. L. Schrock for technical consultation and liaison, all of Westinghouse Advanced Reactors Division, Madison, PA; and R. C. Aungst, Hanford Engineering Development Laboratory, Richland, WA, for assistance in process development and qualification, and procurement of test materials. 


\section{References}

1. N. J. Hoffman, et al, "Evaluation of Cobalt and Nickel-base Materiais for Sliding Contact Applications in a Liquid Metal Fast Breeder Reactor," Proceedings International Conference on Liquid Metal Technology in Energy Production, CONF-760503-P1, ANS-AIME Meeting, Champion, PA 1976.

2. Westinghouse Advanced Reactors Division, Sodium Technology Program Friction, Wear, and Self-Welding Quarterly Progress Report for period ending April 30, 1976, WARD-NA-3045-36, September 1976.

3. Westinghouse Advanced Reactors Division, Sodium Technology Program Friction, Wear, and Self-Welding Quarterly Progress Report for period ending January 31, 1977, WARD-NA-3045-42, April 1977.

4. T. A. Wolf 1 a and R. N. Johnson, "Refractory Metal Carbide Coatings for LMFBR Applications - A Systems Approach," J. Vac. Sci. Technol, Vol. 12, No. 4, pp 777-783, July/August 1975.

5. "Atomics International Annual Technical Progress Report, Sodium Technology and Cover Gas Seal Development Programs. Government Fiscal Year, 1974,"AI-AEC-13132, August 15, 1974.

6. Westinghouse Advanced Reactors Division, Sodium Technology Program Friction, Wear, and Self-Welding Quarterly Progress Report for period ending Apri1 30, 1975, WARD-NA-3045-27, December 1975.

7. Westinghouse Advanced Reactors Division, Sodium Technology Program Friction, Wear, and Self-Welding Quarterly Progress Report for period ending July 31, 1975, WARD-NA-3045-28, December 1975.

8. Liquid Metal Engineering Center Annual Technical Progress Report, January-December, 1975, LMEC 76-1, dated April 30, 1976.

9. Atomics International Annual Technical Progress Report, Sodium Technology and Cover Gas Seal Development Programs. Government i iscal Year 1975, AI-ERDA-13154, August 15, 1975.

10. R. N. Johnson, et al, "Development of Low Friction Materials for LMFBR Components," Proceedings International Conference on Liquid Metal Technology in Energy Production, CONF-760503-P1, ANS-AIME Meeting, Champion PA 1976.

11. R. N. Johnson, et a!, "Wear Resistant Coatings for Reactor Components in Liquid Sodium Environments," J. Vac. Sci. Technol, Vol. 11, No. 4, July/August 1974. 
R. N. Johnson and D. G. Farwick, "Friction, Wear, and Corrosion of Laves-Hardened Nickel Alloy Hardsurfacing in Sodium," HEDL-SA-1391

\section{LIST OF FIGURES}

Figure 1a. Microstructure of Weld-Deposited Tribaloy 700.

Figure 1b. Cross-Sectional Microstructure of Detonation-Gun Coated Tribaloy 700 on Type 316 Stainless Steel.

Figure 1c. Cross-Sectional Microstructure of Plasma-Coated Tribaloy 700 on Type 316 Stainless Steel.

Figure 2. Dynamic Friction Coefficients of Detonation-Gun Applied Tribaloy 700 Rubbed Against Itself in Sodium.

Figure 3. Friction Behavior of Tribaloy 700Against Other Materials in Sodium (Top) and Sodium Vapor Plus Argon (Bottom).

Figure 4. Typical Appearance of Tribaloy 700 Detonation-Gun Coating Following Friction Testing Against Itself in $232^{\circ}$ to $627^{\circ} \mathrm{C}\left(450^{\circ}\right.$ to $\left.1160^{\circ} \mathrm{F}\right)$ Sodium.

Figure 5. Cracking and Spalling Observed in Plasma-Coated Tribaloy 700 After Thermal Cycling Tests in Sodium. Top: Cross-Sectional View. Bottom: Surface Macrophotograph. 

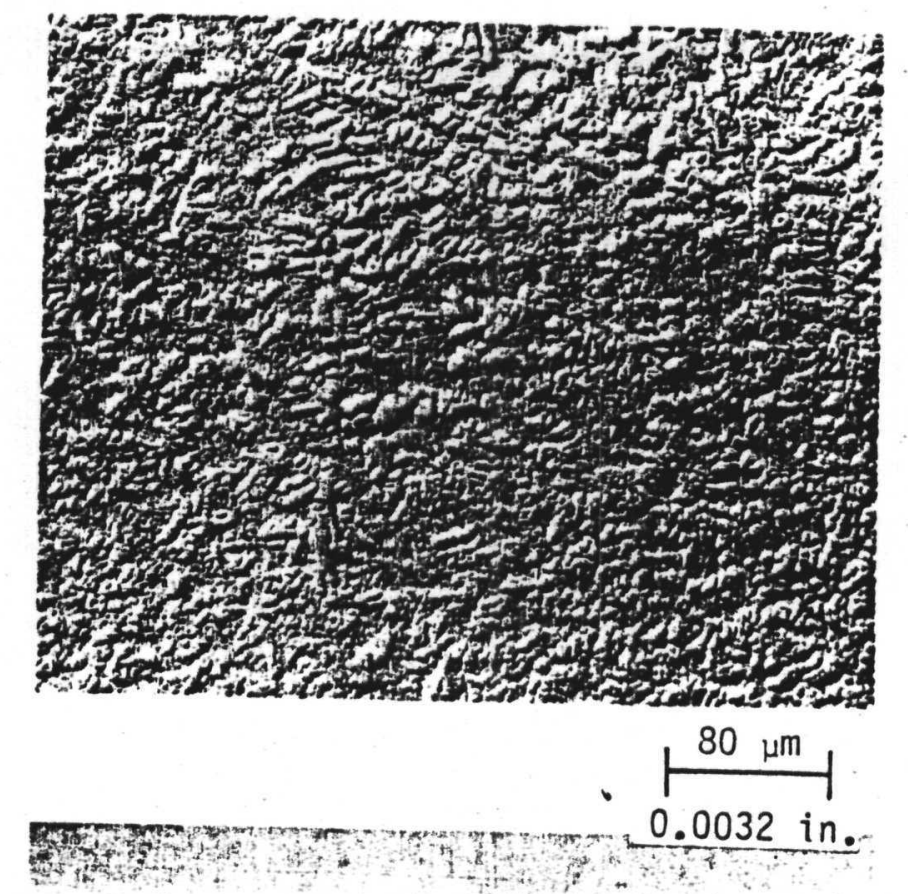

Figure 1a) Microstructure of Weld-Deposited Tribaloy 700

Figure 1b) Cross-Sectional Microstructure of Detonation-Gun Coated Tribaloy 700 on Type 316 Stainless Steel.

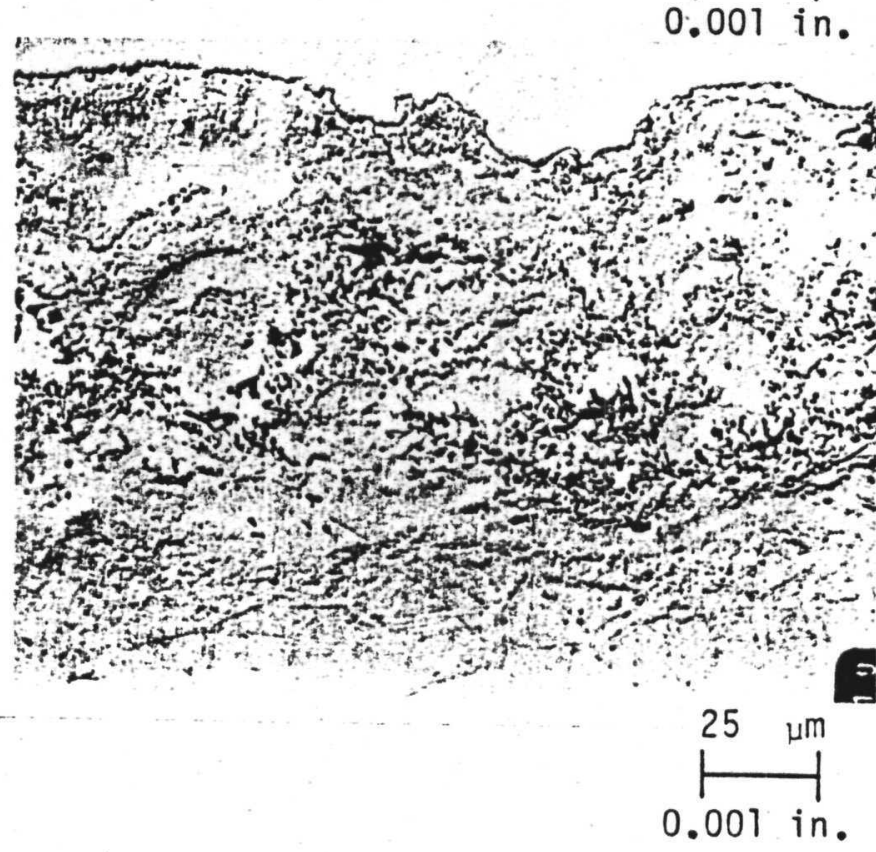

Figure 1c) Cross-Sectional Microstructure of Plasma-Coated Tribaloy 700 on Type 316 Stainless Steel 


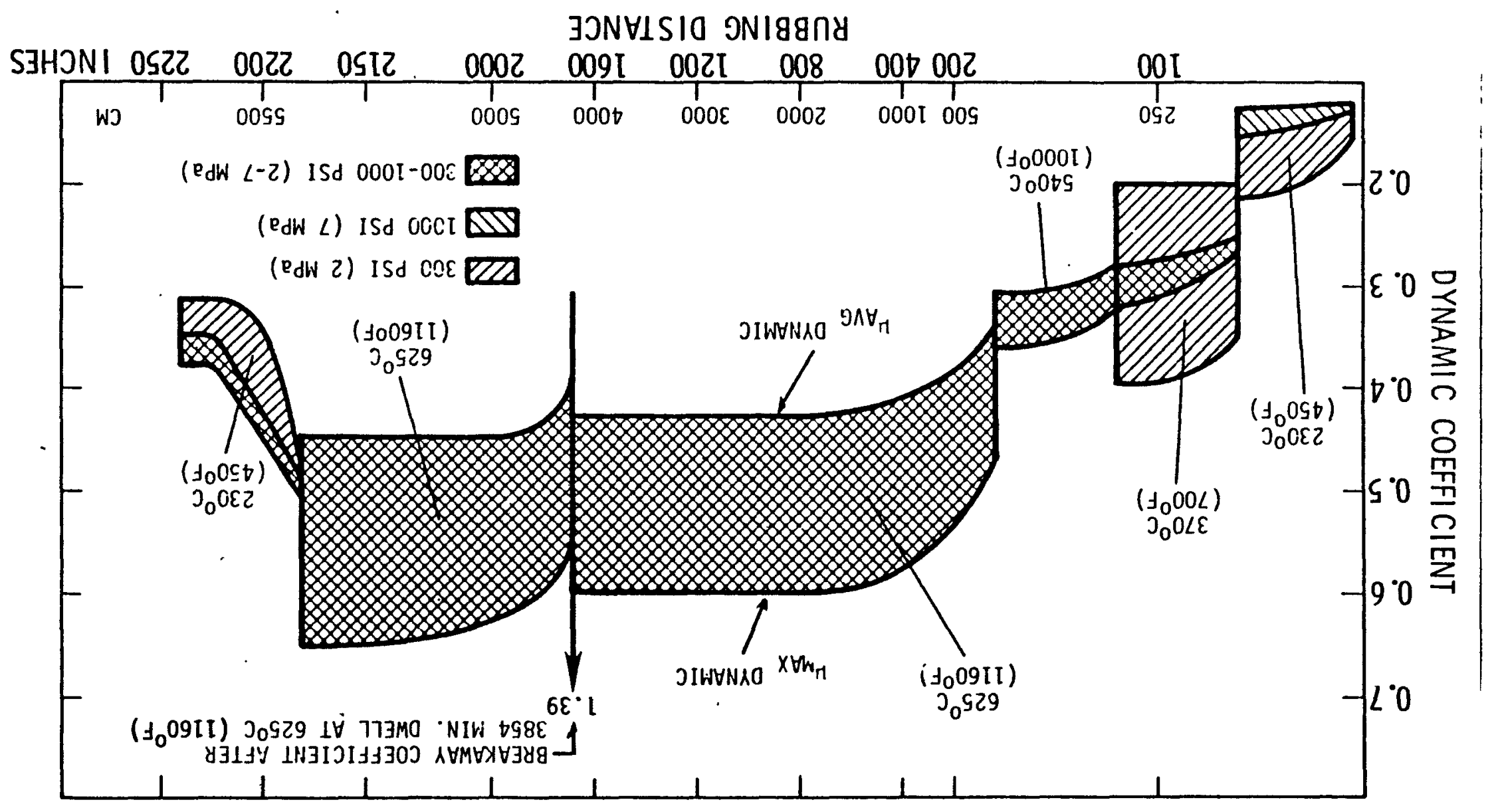



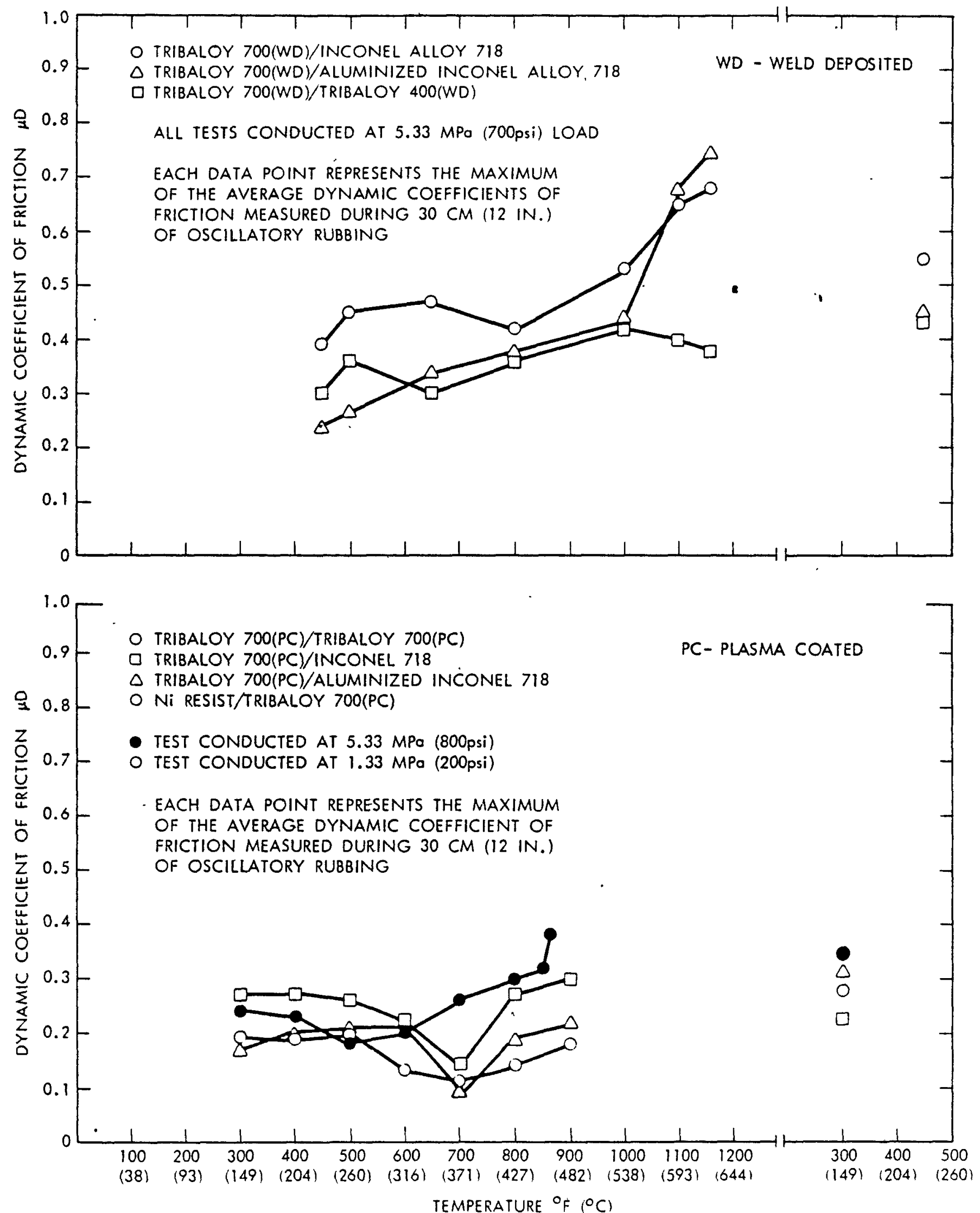

HEOL $7803-93.10$

Figure 3. Friction Behavior of Tribaloy 700 Against Other Materials in Sodium (TOp) and Sodium Vapor Plus Argon (Bottom). 


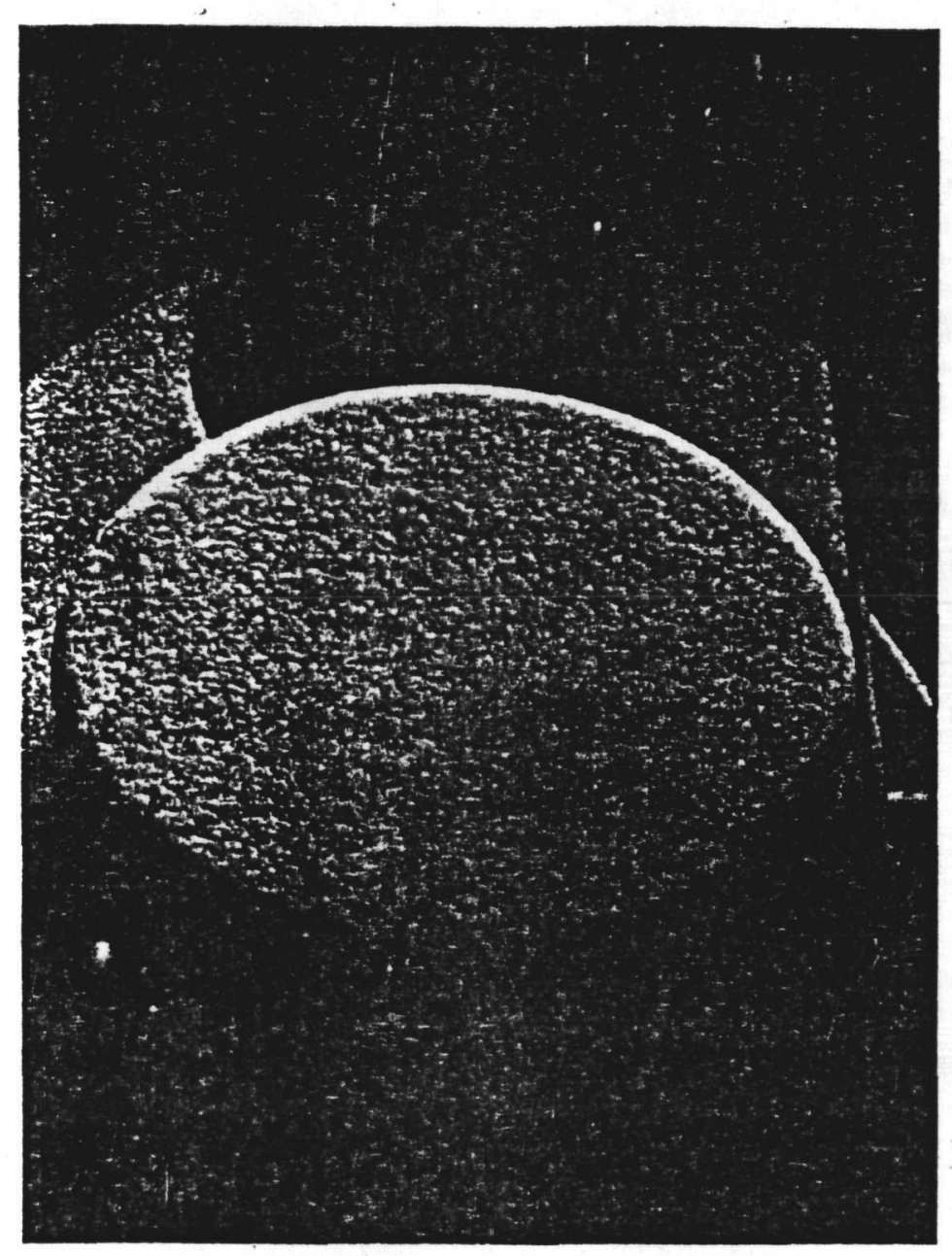

$\underbrace{1.27 \mathrm{~mm}}_{0.05 \mathrm{in} .}$
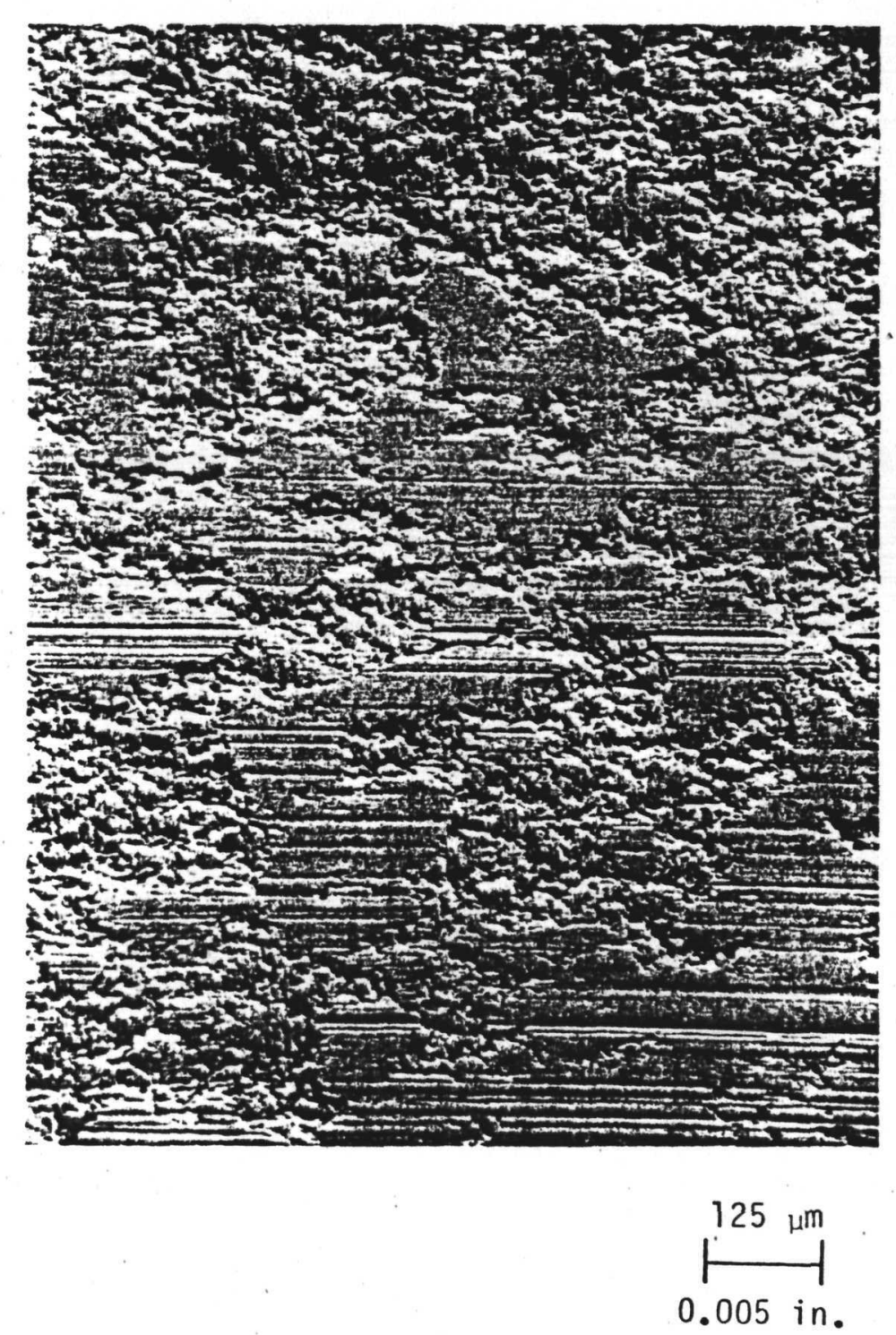

Figure 4. Typical Appearance of Tribaloy 700 Detonation-Gun Coating Following Friction Testing Against Itself in $232^{\circ}$ to $627^{\circ} \mathrm{C}\left(450^{\circ}\right.$ to $\left.1160^{\circ} \mathrm{F}\right)$ Sodium. 

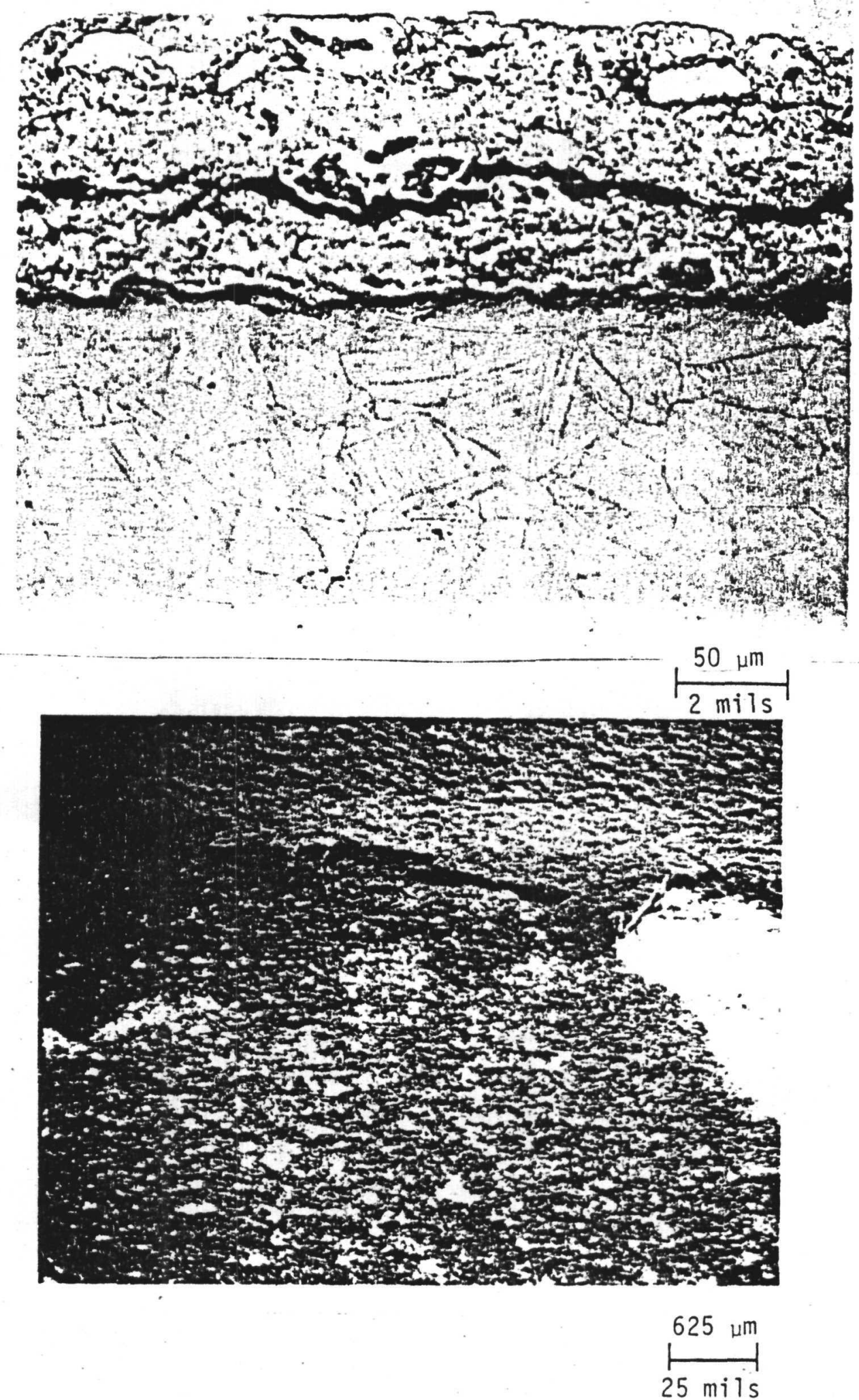

Figure 5. Cracking and Spalling Observed in Plasma-Coated Tribaloy 700 After Thermal Cycling Tests in Sodium. Top: Cross-Sectional View. Bottom: Surface Macrophotograph. 